\title{
Sınıf Öğretmenlerinin Görsel Sanatlar Dersi Alan Bilgisi Öz Yeterlik İnançlari ${ }^{1}$ \\ Buse KIZILIRMAK \\ Marmara Üniversitesi, Atatürk Eğitim Fakültesi, Güzel Sanatlar Eğitimi Bölümü, busekizilirmak@gmail.com
}

Gönderilme Tarihi: 26/06/2018

Kabul Tarihi: $27 / 11 / 2018$

Yayınlanma Tarihi: 30/11/2018
DOI: $\underline{10.30855 / \text { gjes.2018.04.03.003 }}$

\begin{tabular}{|c|c|}
\hline Makale Bilgileri & ÖZET \\
\hline $\begin{array}{l}\text { Anahtar } \\
\text { Kelimeler: }\end{array}$ & $\begin{array}{l}\text { Araştırmada sını öğretmenlerinin görsel sanatlar dersi alan bilgisi öz } \\
\text { yeterlik inançlarının bazı değişkenlere göre incelenmesini ortaya }\end{array}$ \\
\hline $\begin{array}{l}\text { Özyeterlik, } \\
\text { Sınıf Öğretmeni } \\
\text { öz yeterliliği, } \\
\text { Resim eğitimi, } \\
\text { Görsel sanatlar, } \\
\text { Alan bilgisi }\end{array}$ & 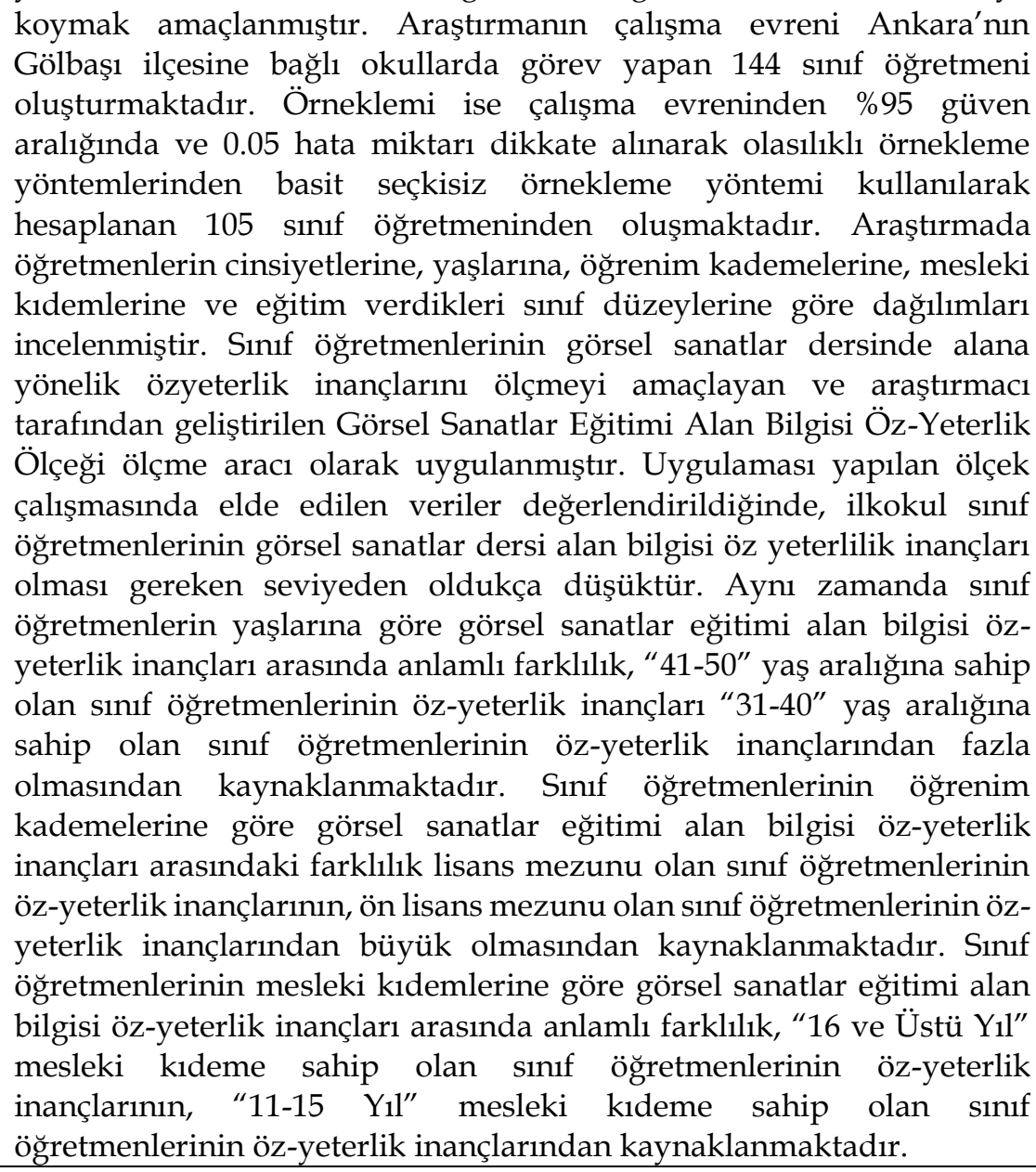 \\
\hline
\end{tabular}

${ }^{1}$ Bu çalışma, Buse Kızılırmak’ın "Sınıf Öğretmenlerinin Görsel Sanatlar Dersi Alan Bilgisi Öz Yeterlilik İnançları" başlıklı Yüksek Lisans tezinden alınmıştır.

Kızılırmak, B. (2018). Sınıf öğretmenlerinin görsel sanatlar dersi alan bilgisi öz yeterlik inançları. Gazi Eğitim Bilimleri Dergisi, 4(3), 29-51. DOI: https://dx.doi.org/10.30855/gjes.2018.04.03.003. 


\section{The Self-sufficiency Beliefs of Classroom Teachers's with Visual Arts Field Information}

\begin{tabular}{|c|c|}
\hline Article Info & ABSTRACT \\
\hline $\begin{array}{l}\text { Keywords: } \\
\text { Self-sufficiency, } \\
\text { Class teachers' } \\
\text { self-sufficiency, } \\
\text { Art education, } \\
\text { Visual arts, } \\
\text { Field knowledge }\end{array}$ & $\begin{array}{l}\text { This research aims to identify the relationship between several variables } \\
\text { and class teachers' confidence in their self-sufficiency for field } \\
\text { knowledge in visual arts lessons. The target population of the study is } \\
144 \text { class teachers working in schools in Gölbaş district of Ankara. The } \\
\text { sample is composed of } 105 \text { class teachers, chosen in accordance with } \\
\text { simple random sampling method, a type of probability sampling, with } \\
\text { a } 95 \% \text { confidence interval and } 0.005 \text { error rate. In the study, the } \\
\text { distribution of teachers according to their sex, age, education level, } \\
\text { occupational seniority and class level they have been trained has been } \\
\text { examined. In order to measure class teachers' confidence in self- } \\
\text { sufficiency for their field knowledge in Visual Art Lessons, a "Self- } \\
\text { Sufficiency Scale for Field Knowledge in Visual Arts Education" which } \\
\text { was developed by the researcher, was used as an assessment and } \\
\text { evaluation measure. When the data obtained from questionnaires are } \\
\text { statistically evaluated, the average scores obtained by class teachers for } \\
\text { self-sufficiency for field knowledge in visual arts indicate that the } \\
\text { confidence levels of the primary school class teachers' levels of } \\
\text { confidence for their field knowledge in visual art lessons are much lower } \\
\text { than what it should be. At the same time, there was a meaningful } \\
\text { difference between self-efficacy beliefs and knowledge of visual arts } \\
\text { education according to the age of classroom teachers. The self-efficacy } \\
\text { beliefs of class teachers with age range "41-50" were higher than self- } \\
\text { efficacy beliefs of class teachers with "31-40". The difference between } \\
\text { self-efficacy beliefs and knowledge of visual arts education according to } \\
\text { the education levels of the class teachers is that the self-efficacy beliefs } \\
\text { of the undergraduate teachers are bigger than the self-efficacy beliefs of } \\
\text { the pre-bachelor's class teachers. There is a significant difference } \\
\text { between self-efficacy beliefs in visual arts education according to } \\
\text { professional seniority of class teachers, self-efficacy beliefs of class } \\
\text { teachers with " } 16 \text { and over year" occupation, self-efficacy of class } \\
\text { teachers with "11-15 years" beliefs are high. }\end{array}$ \\
\hline
\end{tabular}

\section{GİRİş}

İnsanın içinde yaşadığı topluma ve sosyal çevreye entegrasyonunu sağlayabilmesi için bu denli öneme sahip olan sanatın, eğitim dizgisi içerisindeki yeri de o derece önemlidir. Bu noktadan hareketle 19. yüzyılın son çeyreğinde sanatın eğitim boyutu ortaya çıkar. Sanat eğitimi kavramı Avrupa'da "kültür çöküşüne ve insanın kendine yabancılaşmasına karşı bir önlemler hareketi ve eğitim akımı olarak belirmeye başlar" (San, 1983:64). Buna karşın sanat eğitiminin, genel eğitim sistemleri içerisinde yer alarak öğretime girmesi, sonucunda kuram olmaktan çıkarılması ve okullarda ders olarak okutulması ancak 1928'lerde başlayabilmiştir. Bunun öncesinde “1901' de Dresten' de, 1903'te Weimar' da ve 1905' de Hamburg' da yapılan sanat eğitimi kongreleri, sanat eğitiminin okullara girmesinde önemli rol oynamıştır” (San, 1979:2).

İnsanın genel eğitim dizgesi içerisinde önemli bir yere sahip olan sanat eğitimi dersleri, popüler eleştirinin acımasız yaklaşımlarının aksine "sadece yetenekli insanların alması gereken bir "lüks" değil, herkes tarafından alınması gereken bir kişilik eğitimidir. Burada amaçlanan, sanatçı yetiştirmeye yönelik bir eğitim değil, bireyin sanat yoluyla eğitimi, yani bireyin estetik 
eğitimidir" (Gençaydın, 1990:44). Kişilik gelişiminin oluşmasında birey yaşadığı sosyal çevre içerisinde, birçok faktörden etkilenir. Bireyin kişilik gelişimine etki eden önemli faktörlerden biride sanattır. Küçük yaşlardan itibaren, dış dünyaya karşı bir ifade aracı olarak başvurduğu sanat, bireyin sosyal çevreye uyumuna, estetik beğenilerine, duygusal ve mental gelişimine yadsınamaz katkılar sağlar. Bu nedenle kişi sanatsal açıdan doğru bir eğitim anlayışının içerisinde yer almalıdır.

Eğitim dizgisinin ilk basamağını oluşturan ilkokul öğrenimi, örgün eğitimin en önemli parçası konumundadır. Ortaokul, lise ve yükseköğretim gibi daha ileri eğitim basamaklarının temelini oluşturması ve bireylerin öğrenim yaşantılarındaki başarılarını olumlu veya olumsuz etkilemesi bakımından ilkokul öğrenimi, önemli bir işleve sahiptir. (Gültekin, 2000:105) Çocuğun sanatsal gelişimi açısından, ilkokul basamağı sanat eğitimine ilişkin amaçların kazandırılmasında kritik bir dönemi kapsar.

Çocuk gerçek anlamda eğitim almaya başlayacağı okul yıllarının öncesinde, çok küçük yaşlardan itibaren sanatsal bir öğrenmeyle karşı karşıya kalır. Ancak bu öğrenme genel anlamda yaparak, yaşayarak öğrenmenin ötesine geçmez. Örgün eğitim kurumlarında ise sanat dersi geniş kapsamlı bir öğretim alanı olarak göze çarpmaktadır. Bu alan içerisinde; anlatımsal ve teknik açıdan nitelikli ürünler yaratmak, ait olduğu çevrede ve gündelik hayatında karşılaştığı sanat yapıtlarında nitelikler görmek, ayrımsamak, sanat tarihini öğrenmek ve estetik kaygı gütmek ve bilinç kazanmak yer alır (Kırışoğlu, 2002:101).

Öğretmenlik mesleğinin amacı, bireyin gelişimini sağlamak, bireyi sosyalleştirmek, kültürel mirası genç kuşaklarla aktararak toplumun değerlerini bütünleştirmek, bireyi modern gelişmelerini takip etmesini ve de onu yorumlamasını ve bir bakış açısı sağlamak ve bireye bilgi ve deneyimleri ile yol göstermektir. Bireyin bilimsel etik kuralları içerisinde, bilimsel çalışma yapma yeteneğinin kazanmasını da sağlamaktır (Çelikgöz, 2004:351). Başarılı ve yeterli öğretmen, öğretmenlik davranışlarını tam olarak anlamış, hedeflerini bilen, bu hedefler doğrultusunda yöntemler geliştirebilen veya durumun gerektirdiği öğretme yaklaşımını seçebilen ve uygun davranışa dönüştürebilendir. Bir öğretmenin kişilik özellikleri ne kadar olumlu olursa olsun bu özelliklere sahip olmadığı takdirde etkili bir öğretmen olması mümkün değildir (Erden, 1998:43). Öğretmenlik mesleğinin gerektirdiği, tutum davranış, bilgi ve becerinin kazanılması, öğretmen yetiştirme programlarının bireye genel kültür, alan bilgisi ve öğretmenlik meslek bilgisine sahip olacak şekilde yetiştirilmesini zorunlu hale getirmiştir (Celep, 2004:27).

Çocuğun sanatsal gelişiminde önemli bir yere sahip olan ilkokul basamağında sanat eğitiminin farklı uygulama alanları vardır. Bu uygulama alanlarının başında "Görsel Sanatlar Dersi" gelmektedir. Çocuğun sanatsal gelişimi açısından, ilkokul basamağı sanat eğitimine ilişkin amaçların kazandırılmasında kritik bir dönemi kapsar. Özellikle, bireyin sosyal bir varlık olarak gelişmesi, kendini yaşadığı sosyal çevreye ifade edebilmesi ve problem çözmeye yönelik yaratıcı düşüncesinin geliştirmesi açısından ilkokul basamağı büyük önem taşımaktadır. (Türkkan, 2008:7). Çizme, boyama, yırtma, yapıştırma, şekil verme gibi karmaşık süreçler içerisinde çocuk, kendine göre anlamlı bir bütünlük oluşturarak deneyim kazanır. Uygulamasını yaptığı bu etkinlikler neticesinde çocuk, salt bir sanat ürünü ortaya çıkartmakla kalmaz, aynı zamanda kişiliğine yönelik tanıtıı ipuçlarını da bilinçsiz biçimde sunarak bir şekilde kendisini anlatır (Artut, 2009:187).

Türkdoğan'a (1981:17) göre sanat eğitimi; yalnız insana özgü bir gereksinim olduğu varsayımından hareketle, bireyin yaratıcllık gücünü estetik bir düzeye ulaştırmak amacıyla yapılan, yeteneklerini ortaya çıkarmasını sağlayan, duygu, düşünce ve gözlemlerini 
aktarabilmesi için uygun ortamlar gerektiren, donanımlı kişilerin eşliğinde gerçekleşen tüm eğitim çabalarıdır.

Sanat eğitiminin bireylere sağladığı kazanımların çocuklara en etkili biçimde kazandırıldığı basamak ise ilköğretimdir. Sanat eğitiminin ilköğretim basamağındaki uygulama alanlarından biri olan Görsel Sanatlar dersi, çocuğun bu yönde gelişmesinde önemli rol oynamaktadır (Yükselgün, 2010). İlköğretimde Görsel Sanatlar Dersi; bireyin toplumsal bir varlık olabilme, kendini ifade etme, yaratıcılığını geliştirme, içinde yasadığı ortamı tanıma, bir değer olduğunun bilincine vararak kişiliğini geliştirmesine ve kendini gerçekleştirmesine yardımcı olan temel derslerden biridir (Ertemin, 1997:10). Görsel Sanatlar dersi öğrencinin ileriye dönük yaşamında bu kadar önemli bir yere sahipken, bu derse ilkokullarda görsel sanatlar alanında uzman olmayan sınıf öğretmenlerinin girmesi önemli bir sorun teşkil etmektedir. "Sanat eğitiminin amaç ve gerekliliğinin özünde insan ruhunun yüceltilmesi, insanın özgürleşmesi, bireylerin ruhsal gereksinimlerinin doyurulması, dengeli, çağdaş, duyarlı bir toplum yaratılması çabası güdülür." (Artut, 2009:115). Bu çabanın gerçekleştirilmesinde en önemli görev sanat eğitmenlerine düşmektedir.

Öğretmenlerin kendi alanlarına hâkim olmaları, alandaki temel konular ve bunlar arasındaki ilişki ve bağlantıları iyi kavramış olmaları mesleki başarı için kaçınılmazdır (Terzi, Barut ve Gürsoy, 2003:39). Bunun yanı sıra okullarda okutulan her bir dersin öğrencilere kazandıracağı bilgi, beceri, alışkanlık, tutum ve ilgi türünden özellikleri amaçlar adı altında toplanmıştır. Bu bağlamda, görsel sanatlar dersinin amaçları; bireysel ve toplumsal, algısal, estetik ve teknik amaçlar olarak gruplanmıştır (MEB, 2006:8). Görsel sanatlar dersi öğretim planında yer alan öğrenme alanları; görsel iletişim ve biçimlendirme, kültürel miras, sanat eleştirisi ve estetik konularını analiz etmeleri ve yorumlamaları amaçlanmıştır. Aynı zamanda görsel sanatlar dersi öğretmeninin sanatsal tasarım ilke ve elemanlarını, sanat eleştirisinde ki pedagojik eleştiri evrelerini, estetik yargı kuramlarını, yaratıcıllğı ve yaratıcılığa etki eden etmenleri, sanatsal yaratım süreçlerini, çocuk ve resim arasındaki ilişkiyi bilir ve uygular düzeyde olması gerekmektedir. Çocuk resimlerini ve özelliklerini, çocuğun yaşına göre çizgisel gelişim evrelerini bilir ve bu çizgileri yorumlar düzeyde olmaları, çocuğun sanatsal gelişimini algılayabilmesi ya da resimde kendi hayatına dair önemli ipuçları vermesi konusunda öğretmenin alana dair bilgilerini güncel tutması ve alana dair öz-yeterlik inancının yüksek olması beklenmektedir.

Sosyal Öğrenme Teorisi (Social Learning Theory), Sosyal Bilişsel Teori (Social Cognitive Theory) olarak da belirtilen Sosyal öğrenme kuramı, davranışçı kuramların deneysel olarak çok katı olan kuralları ve bazı temel prensiplerinin insan davranışlarını tam olarak açılayamadığ hareketle gelişmiş bir kuramdır. Bu kuramda ağırlıklı olarak bilişsel öğrenme kuramı hakim olduğu için bireyin nasıl öğrendiğiyle ilgilenir (Bandura, 2001; Akt. Demirbaş ve Yağbasan, 2005:367). Bandura tarafından geliştirilen öz yeterlilik inancı, bireylerin sahip oldukları bilgi ve becerileri etkin biçimde kullanabilmeleri için, öncelikle, ilgili alanda kendi yeterliliklerine güven duymaları gerektiğini ortaya atan sosyal biliş kuramına dayanır (Özerkan, 2007:28). Bandura'nın öz-yeterlilik teorisi, öğrenmenin erken dönemlerinde en kolay uygulanabilir olduğunu göstermektedir, bu nedenle öğretimin ilk yılları, öğretmen etkinliğinin öğrencinin uzun vadeli gelişimi için kritik öneme sahip olabilir(Hoy ve Spero, 2005:344) Sosyal öğrenme kuramı içerisinde yer alan öz yeterlilik, kişinin herhangi bir durumda yeterli düzeyde performans göstereceğine duyduğu inançtır. Öz-yeterlilik inancı, algıları, motivasyonu ve performansı oldukça etkiler. (Çakar, 2013:269). 
Öğretmen öz-yeterliği, öğretmenlerin bir öğretme görevini yerine getirme yetenekleri olarak tanımlanır. Öğretmenlerin sanat eğitimi öğretiminde güçlü öğretmen öz-yeterlilikleri varsa, sınıfta öğrenme ortamına sanatı dahil etme olasılıkları daha yüksektir. Aksi halde öğretmen öz-yeterliliğini zayıfsa, sanatın yönlerini müfredatlarına dahil etme olasılıkları oldukça azdır (Garvis ve Pendergast, 2011). Sosyal bilişsel kuramda kurulan öğretmenlerin öz-yeterlik inançları, sürekli olarak olumlu öğretim davranışları ve öğrenci çıktıları ile ilişkilendirilmiştir (Henson, 2001) Öğretme yeterlikleriyle ilgili öz-yeterliliği yüksek ve konularında deneyimli öğretmenler düşük başarılı öğrencileri motive edebilir, bilişsel gelişimlerini güçlendirebilir ve öz yeterliliklerini geliştirebilir. Böylece çocukların kendi performans standartlarını oluşturmalarına ve öz düzenleme yeterliğini kazanmalarına yardım edebilir (Kalkan, 2012:268).

Bandura'nın öz-yeterlilik kuramı; öğretmenlerin yeterliklerine olan inançlarının hangi düzeyde olduğunun ortaya çıkarılması açısından önem taşımaktadır. Kişi, bir görevi yerine getirebilecek yeteneğin kendinde olduğuna inandığı takdirde, görevi yerine getirmeye karşı daha istekli ve kararlıdır. Kişinin kendi becerilerine inanması kişinin başarma isteğini de arttırmaktadır. Bu bağlamda, öz-yeterliği yüksek olan bireyler, kendilerine güven duyarlar ve öğretim konusunda daha arzulu ve tutkuludurlar (Çevik, 2011:149). Çocuklar öğretmenleri tarafından güdülenerek yetenekleri ön plana çıartılmalı, kendilerine olan güvenlerini yitirmelerine müsaade edilmemeli ve her daim çalışma isteklerine şevklendirerek mani olunmalıdır. Başarılı olmaları hâlinde ödüllendirilerek pekiştirilmeli, başarısızlıklarından çok başarıları dile getirilmelidir. (Ateş, 2014:56)

Sonuç olarak, araştırmalar incelendiğinde, öğretmenlerin öğretimle ilgili görevlerini gerçekleştirme konusundaki öz yeterlik inançlarının; çocukların başarılı olmaları için gösterilen çabanın düzeyiyle, öğrencilerin başarıları, sınıf yönetimi becerileri, yöntem tercihleri, güdülenmeleri ve sınıf yönetimi becerileri öğretim için ayrılan zamanın ilişkili olduğu görülmektedir (Benzer, 2011:24). İlköğretimin 1, 2, 3 ve 4. sinıflarında görsel sanatlar dersini yürütmekte olan sınıf öğretmenlerinin, bu derse yönelik pozitif tutumlu olması, ders içi uygulamalarının verimli bir şekilde işlenmesini sağlayarak dersin genel ve özel amaçlarına ulaşmayı kolaylaştırabilecektir. Sınıf öğretmenlerinin resim eğitimine yönelik öz yeterlilik inancı son yıllarda önem kazanan ve üzerinde ciddi bir şekilde durulması gereken konulardan biridir. Yapılan literatür taramasın da sını öğretmenlerinin görsel sanatlar dersi alan bilgisi öz yeterlilik inanışları belirlenmemiştir. Bu konuda kapsamlı bir çalışmanın yapılmamış olması dikkate alınarak, yapılan bu araştırmanın alandaki eksikliği giderebileceği düşünülmüş ve bu çalışmaya ihtiyaç duyulmuştur. Aynı zaman da sınıf öğretmenlerinin görsel sanatlar dersi alan bilgisi öz yeterlik inanç düzeylerinin bilinmesi, sınıf öğretmeni eğitiminde ders müfredatının yeniden incelenmesi veya yapılandırılması bakımından yarar sağlayacağı düşünülmektedir.

$\mathrm{Bu}$ araştırmanın temel amacl, ilkokullarda görev yapan sınıf öğretmenlerinin görsel sanatlar dersi alan bilgisi öz yeterlilik inanışlarını belirlemek ve ortaya çıkan araştırmanın sonuçlarına yönelik önerilerde bulunmaktır. Bu genel amaç doğrultusunda araştırma aşağıdaki alt amaçlara cevap aranacaktır.

1. Sınıf öğretmenlerinin görsel sanatlar eğitiminde alan bilgisine ilişkin öz-yeterlik inançları ne düzeydedir?

2. Sınıf öğretmenlerinin cinsiyetlerine göre görsel sanatlar eğitiminde alan bilgisi özyeterlikleri inançları arasında anlamlı farklılık var mıdır? 
3. Sınıf öğretmenlerinin yaşlarına göre görsel sanatlar eğitiminde alan bilgisi özyeterlikleri inançları arasında anlamlı farklılık var mıdır?

4. Sınıf öğretmenlerinin öğrenim kademelerine göre görsel sanatlar eğitiminde alana yönelik öz-yeterlikleri inançları arasında anlamlı farklılık var mıdır?

5. Sınıf öğretmenlerinin mesleki kıdemlerine göre görsel sanatlar eğitiminde alan bilgisi öz-yeterlikleri inançları arasında anlamlı farklılık var mıdır?

6. Sınıf öğretmenlerinin eğitim verilen sınıf düzeyine göre görsel sanatlar eğitiminde alan bilgisi öz-yeterlikleri inançları arasında anlamlı farklılık var mıdır?

\section{YÖNTEM}

Yapılan araştırmada ilköğretim kurumlarında görev yapan sınıf öğretmenlerinin görsel sanatlar dersi alan bilgisi öz yeterlilik inançlarını belirlemek ve öğretmenlerin cinsiyet, yaş, öğrenim kademesi, mesleki kıdemi, eğitim verdikleri sınıf düzeylerine göre öz yeterlik inançları nasıl farklılık gösterebildiğini ortaya çıkarmak amaçlanmışır. Bu amaç bağlamında yapılan araştırma tarama modeli niteliğindedir. Fraenkel ve Wallen'a (2006) göre “bir konuya ya da olaya ilişkin katılımcıların görüşlerinin ya da ilgi, beceri, yetenek, tutum v.b özelliklerinin belirlendiği genellikle diğer araştırmalara göre görece daha büyük örneklemler üzerinde yapılan araştırmalara tarama araştırmaları" denir.

\section{Evren ve Örneklem}

Araştırmanın amacına uygun olarak evreni Ankara Milli Eğitim Müdürlüğü' ne bağlı ilköğretim okullarıdır. Bu bağlamda maddi olanaklar ve zamanın yetersiz olmasından hareketle evreni temsil edebilecek örneklem seçme şansı olmadığından, bu araştırmada çalışma evreni belirlenmiştir ve seçilen örneklem bu çalışma evrenini temsil etmektedir. Araştırmanın çalışma evreni Ankara'nın Gölbaşı ilçesine bağlı okullarda görev yapan 144 sınıf öğretmeni oluşturmaktadır. Örneklemi ise çalışma evreninden \%95 güven aralığında ve 0.05 hata miktarı dikkate alınarak olasılıklı örnekleme yöntemlerinden basit seçkisiz örnekleme yöntemi kullanılarak hesaplanan 105 sınıf öğretmeninden oluşmaktadır. Seçkisiz örnekleme, örneklemin seçiminde kullanılan bir teknik olup, tanımlanmış bir evrendeki tüm elemanlara, örnekleme seçilmek için eşit ve birbirinden bağımsız şans verir (Özen \& Gül, 2007: 399).

Basit seçkisiz örnekleme yönteminde evrendeki tüm birimler, örneğe seçilmek için eşit ve birbirinden bağımsız şansa sahiptir (Büyüköztürk vd., 2017: 84). Örneklemin demografik özelliklerine ilişkin dağılım Tablo-1'de görülmektedir. 
Tablo 1. Örneklemin Demografik Özelliklerine İlişkin Dağılım

\begin{tabular}{|c|c|c|c|}
\hline Özellikler & Kategoriler & $f$ & $\%$ \\
\hline \multirow{2}{*}{ Cinsiyet } & Kadın & 77 & 73,3 \\
\hline & Erkek & 28 & 26,7 \\
\hline \multirow{4}{*}{ Yaş } & $21-30$ & 17 & 16,2 \\
\hline & $31-40$ & 28 & 26,7 \\
\hline & $41-50$ & 37 & 35,2 \\
\hline & $51-60$ & 23 & 21,9 \\
\hline \multirow{2}{*}{ Öğrenim Kademesi } & Ön Lisans & 18 & 17,1 \\
\hline & Lisans & 87 & 82,9 \\
\hline \multirow{3}{*}{ Mesleki Kıdem } & 10 yil ve alt1 & 24 & 22,9 \\
\hline & 11-15 yıl & 24 & 22,9 \\
\hline & 16 ve Üstü y1l & 57 & 54,3 \\
\hline \multirow{4}{*}{ Eğitim Verilen Sınıf } & 1. Sinif & 19 & 18,1 \\
\hline & 2. Sinif & 25 & 23,8 \\
\hline & 3. Sinif & 25 & 23,8 \\
\hline & 4. Sinif & 36 & 34,3 \\
\hline Toplam & & 105 & 100,0 \\
\hline
\end{tabular}

Tablo 1 incelendiğinde sınıf öğretmenlerinin demografik özelliklerine ilişkin dağılımları incelenmiştir. Öğretmenlerin cinsiyetlerine göre dağılımları incelendiğinde, $77(\% 73,3)$ kadın sınıf öğretmeni ve $28(\% 26,7)$ erkek sınıf öğretmeni bulunmaktadır. Sınıf öğretmenlerinin yaşlarına göre dağılımları incelendiğinde, "21-30" yaş düzeyine sahip olan 17 (\%16,2) öğretmen, "31-40" yaş düzeyine sahip olan $28(\% 26,7)$ öğretmen, "41-50" yaş düzeyine sahip olan $37(\% 35,2)$ öğretmen ve "51-60" yaş düzeyine sahip olan 23 (\%21,9) öğretmen bulunmaktadır. Öğretmenlerin öğrenim kademesine göre dağılımları incelendiğinde, ön lisans mezunu olan 18 $(\% 17,1)$ öğretme ve lisans mezunu olan $87(\% 82,9)$ öğretmen bulunmaktadır. Öğretmenlerin mesleki kıdemlerine göre dağılımları incelendiğinde, "10 yıl ve altı" mesleki kıdeme sahip olan $24(\% 22,9)$ öğretmen, "11-15 yll" mesleki kıdeme sahip olan 24 (\%22,9) öğretmen ve "16 ve üstü yıl” mesleki kıdeme sahip olan $57(\% 54,3)$ öğretmen bulunmaktadır. Sınıf öğretmenlerinin eğitim verdikleri sınıflara göre dağılımları incelendiğinde, 1 . Sınıf düzeyinde eğitim veren $19(\% 18,1)$ sınıf öğretmeni, 2. Sınıf düzeyinde eğitim veren $25(\% 23,8)$ sınıf öğretmeni, 3. Sınıf düzeyinde eğitim veren $25(\% 23,8)$ sinıf öğretmeni ve 4 . Sınıf düzeyinde eğitim veren $36(\% 34,3)$ sinıf öğretmeni bulunmaktadır. Genel itibari ile bakıldığında araştırmada yer alan $105(\% 100,0)$ sınıf öğretmeni bulunmaktadır.

\section{Veri Toplama Araçları}

Ölçme aracının geliştirilme aşamasında Çatıkkaş (2014) tarafından geliştirilen "Görsel Sanatlar Eğitimi Öz-Yeterlik Ölçeği" nden yararlanılmıştır. 72 maddelik deneme ölçeğinden hareketle uzman görüşleri alınarak 43 maddeye düşürülmüş ve sonradan 8 madde daha çıarılarak 35 maddelik son şekli deneme uygulamasına tabi tutulmuştur. "Kesinlikle 
Katılmıyorum", “Katılmıyorum", “Kararsızım", “Katılıyorum" ve "Tamamen Katıliyorum"

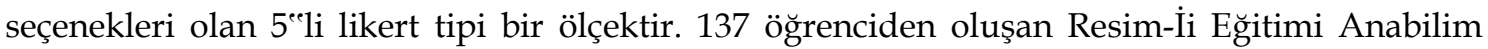
Dalında öğrenim gören öğrenci grubuna uygulama yapılmıştır. KMO değeri 0,80 olarak bulunmuştur. Öz değerleri incelendiğinde tek bir faktörde maddelerin toplandığı görülmektedir. Tek faktörlü yapıya ait maddelerin faktör yük değerleri 0,35 ile 0,85 aralığında değişmektedir. Ölçeğin Cronbach Alpha iç tutarlık katsayısı 0,94 olarak hesaplanmıştır.

Çatıkkaş tarafından Resim-İş Eğitimi Anabilim Dalında öğrenim gören öğrencilere uygulama yapılarak geliştirilen ölçeğin hem tek faktörlü yapıda olması hem de bu araştırmada örneklem grubunun farklı olmasından dolayı yapının tekrardan kontrol edilmesi gerekliliği sonucu ortaya çıkmaktadır. Daha önceden geliştirilen 35 tane ölçek maddesine araştırmacı tarafından uygulama yapılan örneklem özelliğine uygun olarak, literatür taranmış ve uzman görüşü alınmıştır. Uzmanlar Güzel Sanatlar Eğitimi (5) ve Ölçme Değerlendirme (1) alanlarında öğretim elemanlarıdır. Görüşler doğrultusunda 5 madde eklenmiştir. Araştırmacı tarafından yeni oluşturulan 40 maddelik ölçek formu tekrar uzman görüşüne tabi tutularak daha geliştirilmiş olan tek faktörlü 35 maddelik yapıda yer alan 1 madde daha çıkarılmıştır ve 39 maddelik son hali oluşturulmuştur. Yapıyı bozmamak adına 39 madde 105 sınıf öğretmenine uygulanmış ve Açıklayıcı Faktör Analizi yapılırken tek faktörlü yapı dikkate alınmıştır. Nihai olarak geliştirilen ve uygulanan ölçek içerisindeki 39 maddelik sorular şu şekildedir;

1) Çocukların yaş düzeylerine uygun çizgisel gelişim basamakları konusunda yeterli bilgi birikimine sahibim

2) Çocukların yaşlarına göre resimsel özellikleri hakkında yeterli bilgiye sahibim (Boy hiyerarşisi, saydamlık, düzleme özelliği vs.)

3) Çocukları resimsel özelliklerine göre değerlendirebilirim (Yapıcı, görücü ve karışık tip)

4) Dersi etkin kılmak için farklı materyaller tasarlayabilir, farklı teknikler uygulatabilirim

5) Güncel sanatsal gelişmeler ve etkinlikler hakkında öğrencilerimi bilgilendiririm.

6) Öğrencilerimin geliĢim düzeylerine uygun uygulamalar yaptırabilirim.

7) Öğrencilerimin bireysel farklılıklarına göre ders işleyebilirim.

8) Öğrencilerime özgün sanat çalışmaları yaptırabilirim.

9) Alanımla ilgili gelişmeleri uygulayabilirim.

10) Afiş, broşür ve logo gibi grafik tasarımları yaptırabilirim.

11) Kil, alçı ve yutong gibi malzemeler kullanarak öğrencilerime heykel çalışması yaptırabilirim.

12) Baskı tekniği uygulamaları yaptırabilirim.

13) Sanat ürünlerinde özgün olmaları için öğrencilerimi teşvik edebilirim.

14) Bir sanat eserinin ortaya çıktığı dönemde kullanılan araç-gereç, malzeme, üslup ve sanat tarzı hakkında bilgi verebilirim.

15) Bir sanatçının eseriyle sahip olduğu düşünsel, dinsel, kültürel ve sosyal çevresi arasında ilişki kurabilirim.

16) Bir sanat eserinin ortaya çıktığı tarihsel, kültürel veya sosyal çevre hakkında konuşabilirim.

17) Görsel sanatlar dersini diğer derslerle ilişkilendirebilirim.

18) Sınıfa ressamlardan örnek çalışmalar getirerek bunlardan yararlanabilirim.

19) Bir sanat eserinin tarihsel ve kültürel anlamı hakkında bilgi verebilirim.

20) Öğrencilerimin kendi sanat ürünlerine yönelik özdeğerlendirme yapmalarını sağlayabilirim.

21) Öğrencilerimin bir sanat eserini anlamalarını sağlayabilirim.

22) Bir sanat eserinde hangi araç ve gereçlerin kullanıldığını belirtebilirim.

23) Öğrencilerimin bir sanat eserinin hangi teknikle yapıldığını görmelerini sağlayabilirim.

24) Öğrencilerime bir sanat eserine sanatsal gözle bakmayı öğretebilirim. 
25) Bir resimde ışık, gölgeleme ve derinlik hakkında öğrencilerime bilgi verebilirim.

26) Bir sanat eserinin toplumsal ve kültürel önemi üzerinde konuşabilirim.

27) Öğrencilerime sanat eserlerini sorgulatabilirim.

28) Öğrencilerimin estetik algılarını zenginleştirebilirim.

29) Öğrencilerimin iyi düşünülmüş estetik yargı vermelerinde onları eğitebilirim.

30) Öğrencilerimin estetik tavırlarını tanırım.

31) Öğrencilerimin estetik beğeni yargılarını geliştirebilirim.

32) Öğrencilerimin estetik yaşantılarını geliştirecek etkinlikler yapabilirim.

33) Öğrencilerimin bir sanat eserinden estetik haz almalarına katkı sağlayabilirim.

34) İnsanların estetik eğilimi olup olmadıklarını ayırt edebilirim.

35) Sanat eserinin ana konusu hakkında bilgi verebilirim.

36) Bir resmin ortaya çıkardığı güzellik hazzını betimleyebilirim.

37) Öğrencilerimin estetik duyarlılığını artıracak etkinlikler yapabilirim.

38) Bir sanat eseri ile onu izleyenlerinin duygusal yaşantıları arasında ilişki kurabilirim.

39) Öğrencilerimin bir eseri neden güzel bulduklarını ortaya çıkaracak ölçütler tespit edebilirim.

Ölçeğin uygulama grubunda nasıl bir yapı gösterdiği geçerlik ve güvenirlik çalışmaları aşağıda verilmiştir.

\section{Görsel Sanatlar Eğitimi Alan Bilgisi Öz-Yeterlik Ölçeği Geçerlik Çalışması}

\section{Açıklayıcı Faktör Analizi}

Ölçeğin, yapı geçerliği faktör analizi kullanılarak analizleri yapılmıştır. Öncelikle deneme uygulamasından elde edilen verilerin faktör analizine elverişli olup olmadığı incelenmiş ve bu verilerin uygunluk sonuçları Kaiser-Meyer-Olkin (KMO) ve Bartlett testleri ile analiz edilmiştir. Bu sonuçlar aşağıda Tablo-2'de görüldüğü gibidir.

Tablo 2. KMO ve Bartlett Testi SonuçlarıVerilerin Analizi

\begin{tabular}{|c|c|c|}
\hline Kaiser-Meyer-Olkin Örneklem Uyum Ölçüsü & & ,90 \\
\hline \multirow{3}{*}{ Bartlett Küresellik Testi } & $X^{2}$ & 5329,44 \\
\hline & Sd & 741 \\
\hline & $\mathrm{p}$ & ,000 \\
\hline
\end{tabular}

Tablo 2' de görüldüğü üzere, hesaplanan KMO uyum ölçüsü değeri 0,90'dır. Leech, Barrett ve Morgan (2005); Şencan (2005) e göre kritik değer olarak 0,50'ye göre bu değerin altında faktör analizinin uygulanamayacağı belirtilmiştir (Büyüköztürk vd., 2010: 207). Ölçeğe ait KaiserMeyer-Olkin değeri kritik değerler karşılaştırıldığında "0.90-1.00" çok yüksek düzeyde olduğu tespit edilmiştir (Büyüköztürk vd.,: 207). Aynı veriler için hesaplanan Bartlett Küresellik Testi 5329,44 olup 0,00 düzeyinde anlamlıdır $(X 2741=5329,44)$. Bu değerlere, deneme uygulamasından elde edilen verilerin faktör analizine uygulanabileceğini göstermektedir. Buradan da uygulama yapılan örneklem sayısının faktör analizini uygulayabilmek için yeterli olduğu sonucuna varılmıştır.

Temel bileşenler analizi kullanılarak yapılan faktör analizi sonuçları aşağıda verilmiştir. 
Tablo 3. Faktör Özdeğerleri ve Açıklama Varyansları

\begin{tabular}{lccc}
\hline Faktör & Başlangıç Özdeğer & \\
\hline & Toplam & Varyans $\%$ & Toplam Varyans \% \\
\hline $\mathbf{1}$ & 23,80 & 61,03 & 61,03 \\
\hline $\mathbf{2}$ & 3,25 & 8,33 & 69,35 \\
\hline $\mathbf{3}$ & 1,56 & 4,00 & 73,35 \\
\hline $\mathbf{4}$ & 1,07 & 2,74 & 76,09 \\
\hline
\end{tabular}

Tablo 3' de görüldüğü üzere, öz değeri 1,0'den büyük 4 faktör vardır. Ancak Faktörlerin toplam varyansa katkısına bakıldığında 1 . Faktörün toplam varyansa katkısı \%61,03 olduğu ve diğer faktörlerin varyansa olan katkılarından çok düşük olmasından dolayı ölçeğin tek faktörlü bir yapıda olduğu görülmektedir. Bu bir faktörün açıkladığı varyans, toplam varyansın \% 61,03' dür. Başlangıç öz değerleri dikkate alındığında, birinci faktöre ait öz değerin 23,80 olduğu ve diğer faktörlerin öz değerlerinden çok küçük olmasından dolayı tek faktörlü yapıda olduğu sonucuna ulaşılmıştır.

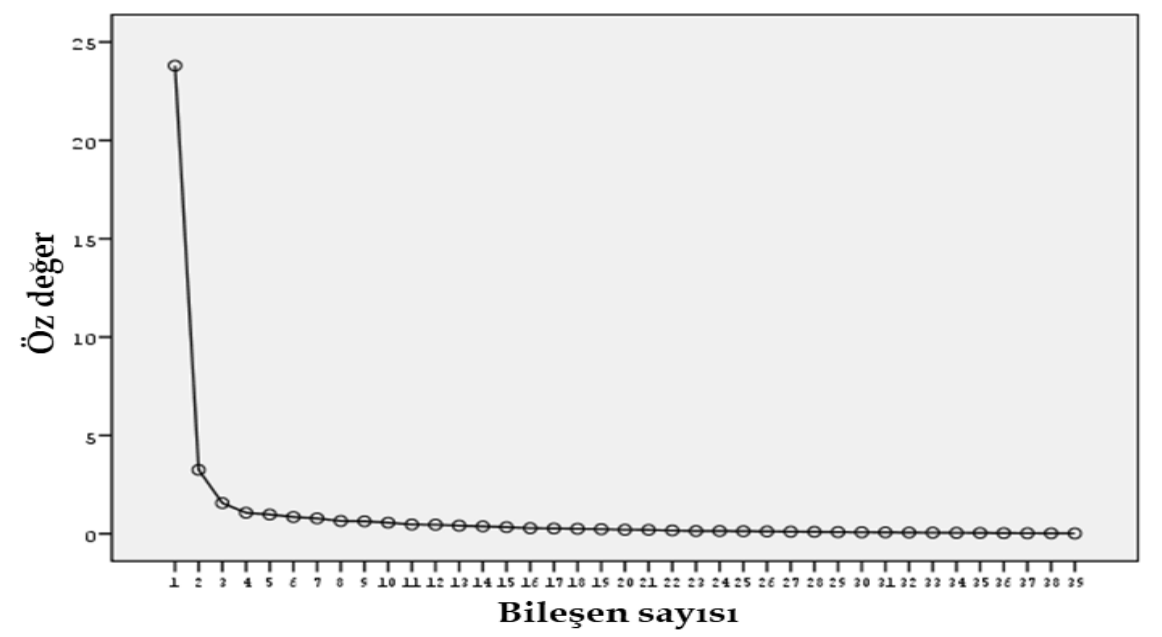

Şekil 1. Ölçeğin Faktörlerine İlişkin Yamaç-Birikinti Grafiği

Şekil-1'e bakıldığında Ölçeğin tek bir faktörde büyük bir eğim gösterdiği ve ikinci faktöre geçiş sırasında kırılmanın düzgünleştiği sonucuna ulaşılmıştır. Yamaç-birikinti grafiğine bakıldığında ölçeğin tek bir faktörde açıklanabileceği sonucuna ulaşılmıştır. Deneme formunda yer alan maddelerin hangi faktör yük değerine sahip oldukları Tablo 4 'te verilmiştir. 
Görsel Sanatlar Dersi Alan Bilgisi Öz Yeterlik İnancı (Kızllırmak)

Tablo 4. Maddelere Ait Faktör Yük ve Madde Toplam Korelasyon Sonuçları $\left({ }^{*} \mathrm{p}<, 05\right)$

\begin{tabular}{|c|c|c|}
\hline & Faktör Yükleri & Madde-Toplam Korelasyonu \\
\hline $\mathrm{m} 1$ & 0,77 & $0,76\left(^{*}\right)$ \\
\hline $\mathrm{m} 2$ & 0,75 & $0,73\left(^{*}\right)$ \\
\hline $\mathrm{m} 3$ & 0,69 & $0,67\left(^{*}\right)$ \\
\hline $\mathrm{m} 4$ & 0,82 & $0,82\left(^{*}\right)$ \\
\hline m5 & 0,83 & $0,82\left(^{*}\right)$ \\
\hline $\mathrm{m} 6$ & 0,80 & $0,79\left(^{*}\right)$ \\
\hline $\mathrm{m} 7$ & 0,71 & $0,70\left(^{*}\right)$ \\
\hline $\mathrm{m} 8$ & 0,73 & $0,73\left(^{*}\right)$ \\
\hline $\mathrm{m} 9$ & 0,77 & $0,76\left(^{*}\right)$ \\
\hline m10 & 0,84 & $0,83\left(^{*}\right)$ \\
\hline $\mathrm{m} 11$ & 0,79 & $0,78\left(^{*}\right)$ \\
\hline $\mathrm{m} 12$ & 0,86 & $0,85\left(^{*}\right)$ \\
\hline m13 & 0,84 & $0,83\left(^{*}\right)$ \\
\hline m14 & 0,83 & $0,81\left(^{*}\right)$ \\
\hline m15 & 0,82 & $0,80\left(^{*}\right)$ \\
\hline m16 & 0,76 & $0,74\left(^{*}\right)$ \\
\hline m17 & 0,79 & $0,77\left(^{*}\right)$ \\
\hline m18 & 0,59 & $0,58\left(^{*}\right)$ \\
\hline m19 & 0,87 & $0,86\left(^{*}\right)$ \\
\hline $\mathrm{m} 20$ & 0,68 & $0,66\left(^{*}\right)$ \\
\hline $\mathrm{m} 21$ & 0,62 & $0,61\left(^{*}\right)$ \\
\hline $\mathrm{m} 22$ & 0,50 & $0,50\left(^{*}\right)$ \\
\hline $\mathrm{m} 23$ & 0,39 & $0,39\left(^{*}\right)$ \\
\hline $\mathrm{m} 24$ & 0,50 & $0,50\left(^{*}\right)$ \\
\hline m25 & 0,38 & $0,37\left(^{*}\right)$ \\
\hline $\mathrm{m} 26$ & 0,81 & $0,79\left(^{*}\right)$ \\
\hline $\mathrm{m} 27$ & 0,83 & $0,82\left(^{*}\right)$ \\
\hline $\mathrm{m} 28$ & 0,89 & $0,88\left(^{*}\right)$ \\
\hline m29 & 0,89 & $0,88\left(^{*}\right)$ \\
\hline m30 & 0,87 & $0,86\left(^{*}\right)$ \\
\hline m31 & 0,88 & $0,86\left(^{*}\right)$ \\
\hline m32 & 0,92 & $0,91\left(^{*}\right)$ \\
\hline m33 & 0,89 & $0,88\left(^{*}\right)$ \\
\hline m34 & 0,86 & $0,84\left(^{*}\right)$ \\
\hline m35 & 0,84 & $0,83\left(^{*}\right)$ \\
\hline m36 & 0,80 & $0,78\left(^{*}\right)$ \\
\hline m37 & 0,88 & $0,87\left(^{*}\right)$ \\
\hline m38 & 0,84 & $0,83\left(^{*}\right)$ \\
\hline m39 & 0,88 & $0,87\left(^{*}\right)$ \\
\hline
\end{tabular}


Tablo 4'e bakıldığında 1., 2., 3., 4., 5., 6., 7., 8., 9., 10., 11., 12., 13., 14., 15., 16., 17., 18., 19., 20., 21., 22., 23., 24., 25., 26., 27., 28., 29., 30., 31., 32., 33., 34., 35., 36., 37., 38. ve 39. Maddeler birinci faktörde en yüksek yük değerine sahip olduğu görülmektedir. Tek Faktörde maddelerin faktör yüklerine bakıldığında 0,38 ile 0,92 arasında değişmektedir. Bu yük değerlerine göre ölçek tek faktörlü olup tüm maddeler ölçekte yer alabilecek yük değerine sahiptir. Tabachnick ve Fidell'e (2001)'e göre her bir maddenin yük değerinin 0,32 kritik değerin üstünde olması halinde "kabul edilebilir" olduğu belirlenmiştir (Büyüköztürk vd.,: 2010). Belirlenen faktörün açıklama varyansını artırmak için sınır değer olarak, 40 faktör yükü belirlenmiştir.

Madde toplam korelâsyonuna dayalı olarak yapılan madde analizi sonuçları Tablo-4'te verilmiştir. Bu sonuçlara göre korelasyon değerleri $r=, 37(\mathrm{~m} 25)$ ile $\mathrm{r}=, 91$ (m32) arasında değişmektedir ve 0,05 düzeyinde anlamlıdır. Nihai ölçek formunda olan 39 maddenin, madde toplam korelasyonları kabul edilebilir niteliktedir, yani ölçeğin geneliyle ölçülebilecek özelliğin her bir madde ile ölçülmeye çalışılan özelliğin aynı olduğu dolayısıyla 39 maddenin ölçekte yer alabilecek niteliğe sahip olduğu söylenebilir.

\section{Görsel Sanatlar Ĕ̆itimi Alan Bilgisi Öz-Yeterlik Güvenirlik Çalışması}

Ölçeğin güvenirliği için Görsel Sanatlar Eğitimi Öz-Yeterlik ölçeğinin bir faktörü için belirlenen maddelerin Cronbach Alpha iç tutarlılık katsayılarına bakılarak tablo-5'te gösterilmiştir. Bu katsayı, tüm maddeler dikkate alınarak hesaplandığından, ölçme aracının genel güvenirlik yapısını diğer katsayılara göre en iyi yansıtan katsayıdır (Özdamar, 2004).

Tablo 5. Faktörlere Ait Alfa Güvenirlik Katsayıları

Görsel Sanatlar Eğitimi Öz-Yeterlik Ölçeği

\begin{tabular}{ll}
\hline Madde Sayısı & 39
\end{tabular}

Cronbach a

,98

Tablo 5'e göre Cronbach alpha iç tutarlılık katsayıları Görsel Sanatlar Eğitimi Alan Bilgisi Öz-Yeterlik Ölçeğinde 39 madde ile, 98 güvenirlik katsayısına sahip olduğu görülmektedir. Özdamar (2004), 0.90-1.00 arasında değişen güvenirlik katsayısının yüksek düzeyde güvenilir olduğunu belirtmiştir. Bu ölçeğin güvenirlik katsayısının yüksek düzeyde güvenilir olduğu sonucuna ulaşılmıştır. Bu da ölçeğin kabul edilebilir düzeyde iç tutarlılığa sahip olduğunu göstermektedir. Tezbaşaran (1997:47); likert tipi bir ölçekte yeterli sayılabilecek bir güvenirlik katsayısının olabildiğince 1'e yakın olması gerektiğini ifade etmektedir. Bu sonuçlara göre araştırma için kullanılan ölçeğin tamamının güvenirliğinin yüksek düzeyde olduğu görülmektedir.

\section{Verilerin Analizi}

Geliştirilen 39 maddelik nihai ölçek formu sınıf öğretmenlerden oluşan 105 katılımcı grubundan toplanan verilere SPSS-21 paket programına işlenerek maddelerin yapı geçerliğinin test edilmesi amacı ile açıklayıcı faktör analizi, madde geçerliğine kanıt sağlamak amacı ile madde toplam korelasyon analizi, verilerin temel bileşenler analizine uygunluğunu saptamak amacı ile Kaiser-Meyer Olkin (KMO) katsayısı ve Barlett Sphericity testi dikkate alınarak değerlendirme yapılmıştır. Ölçeğin güvenirliğini test etmek için iç tutarlık katsayısı olan Cronbach Alpha güvenirlik katsayısına bakılmıştır. Araştırma kapsamında kullanılan görsel sanatlar eğitimi alan bilgisi öz-yeterlik ölçeğinden elde edilen puanların dağılımına ilişkin betimsel istatistiklere bakılmıştır. Öğretmenlerin demografik özelliklerine göre öz-yeterlik 
algıları arasındaki farklılıklara bakmadan önce veri dağılımının parametrik veya nonparametrik olup olmadığına karar vermek için normallik ve levene homojenlik testleri yapılmıştır. Ölçeklerden elde edilen öğretmenlerin öz-yeterliklerini yansıtan puanların normal dağılım varsayımının sınanması için Kolmogorov-Smirnov $Z$ testi incelemiş ve $Z=1,13, p=, 154>, 05$ 'e göre puan dağılımının normal dağıldığı yani normallik varsayımını sağladığı görülmektedir. Öğretmenlerin öz-yeterliklerine ilişkin test varyanslarının homojenliği yani Levene homojenlik testine ait dağılım incelendiğinde Levene İstatistiği $=1,60, p=, 195>, 05$ 'e göre puan dağılımına ait test varyanslarının homojen dağıldığı yani homojenlik varsayımının sağlandığ1 sonucuna ulaşılmıştır. Ölçeğe ait elde edilen puan dağılımının sürekli veri olduğu ve eşit aralıklı ölçek düzeyinde olduğu görülmektedir. İki örneklemin (grup) birbirinden bağımsız olması, bağımlı değişkenlerin aralık veya oran ölçek düzeyinde ölçülmüş olması, normallik ve homojenlik varsayımlarının sağlanması parametrik test varsayımlarını karşılamaktadır. Grup sayıları kimilerine göre 30 ve kimilerine göre $15^{\prime}$ in altına düştügüunde puanların normal dağıldığını varsaymak güçtür. Bununla birlikte küçük gruplu deneysel çalışmalar yapan araştırmacıların, topladıkları verilerin dağılımlarının uygun olması durumunda parametrik istatistikleri kullandıkları görülmektedir (Büyüköztürk vd., 2017: 152-161). Bu bağlamda araştırmada yer alan tek faktörlü dağılımın parametrik test varsayımlarını karşıladığı ve puan dağılımının normal dağılım sergilemesinden dolayı gruplardaki örneklem büyüklüklerinin 30'dan küçük olmasının parametrik test varsayımını etkilemediği söylenebilmektedir. Sınıf öğretmenlerinin cinsiyetleri ve öğretim kademesine göre öz-yeterlik inançları arasındaki farklılığa Independent-Sample TTesti analizi ile bakılmıştır. Sınıf öğretmenlerinin yaş, mesleki kıdem ve eğitim verdikleri sınıf düzeylerine göre öz-yeterlik inançları arasındaki farklılığa One-Way ANOVA analizi ile bakılmıştır.

\section{BULGULAR}

Bu bölümde araştırmanın amacı doğrultusunda belirlenen alt amaçlara ilişkin bulgular yer almaktadır.

Birinci Alt Problem: Sınıf öğretmenlerinin görsel sanatlar eğitimi alan bilgisine ilişkin özyeterlikleri inançları ne düzeydedir?

Tablo 6. Öğretmenlerin Alan Bilgisi Öz-Yeterliklerine İlişkin Betimsel İstatistikler

\begin{tabular}{lccccc}
\hline & $\mathrm{N}$ & Minimum & Maximum & $\bar{X}$ (Ortalama) & S (Standart Sapma) \\
\hline Öz-Yeterlik & 105 & 39,00 & 167,00 & $99,91(2,56)$ & 30,52 \\
\hline $\begin{array}{l}\text { Kriterler: } \\
\text { yüksek }\end{array}$ & $112,92 / 39=2,90$ & $1-1,79=$ çok düşük; $1,80-2,59=$ düşük; $2,60-3,39=$ orta; 3,40-4,19=yüksek; 4,20-5,00=çok
\end{tabular}

Tablo 6'ya bakıldığında ilköğretim kurumlarında görev yapan sınıf öğretmenlerinin görsel sanatlar eğitimi alan bilgisi öz-yeterlik inançlarını belirlemeye ilişkin betimsel istatistikler incelenmiştir. Öğretmenlerin öz-yeterlikleri 39 maddelik algı ölçeğine vermiş oldukları cevaplardan yola çıkarak toplam öz-yeterlik inançlarına yönelik dağılıma bakıldığında; $X=99,91$ $(30,52)$ olduğu görülmektedir. Toplam puan verileri madde sayısına bölünerek elde edilen ortalama puanın 2,56 olduğu görülmektedir. Sınıf öğretmenlerinin görsel sanatlar eğitimi alan bilgisi öz-yeterlik ortalama puanları incelendiğinde düşük düzeyde $(1,80-2,59)$ inanca sahip oldukları görülmektedir. Öğretmenlerin öz-yeterlik inançlarına ait minimum puanın 39,00 olduğu ve maksimum puanın 167,00 olduğu, yani 128 puanlık bir ranja (dizi genişliğine=167-39) 
sahip olduğu görülmektedir. Genel itibari ile öğretmenlerin alan bilgisi öz-yeterlik inançarının düşük düzeyde olduğu sonucuna ulaşılmıştır.

Görsel sanatlar dersi, diğer mihver derslerdeki kuramsal yapıdan uzak, farklı yaklaşım, strateji, yöntem ve uygulamaları bünyesinde barındıran çok yönlü bir eğitim alanıdır. Buradan elde edilen bulgulara göre, sını öğretmenlerinin görsel sanatlar eğitimi alan bilgisine yönelik özyeterlik inançlarının düşük düzeyde olması, dersi yürütmekte olan öğretmenlerin, dersin gerektirdiği bilgi birikimi, beceri ve donanıma sahip olmamalarından kaynaklanmış olabileceği söylenebilir. Hazırlanan anketin uygulama aşamasında sınıf öğretmenleri soruları cevaplarken, kendilerini görsel sanatlar dersi adına yeterli bulup bulmadıklarını sorulduğunda, alınan cevap bu alt amaç için çıkan sonucu doğrular nitelikte kendilerini yetersiz buldukları olmuştur. Bu dersin öneminin farkında olmaları ancak diğer ders yüklerinden dolayı gerekli özeni gösteremediklerinin için desteğe ihtiyaç duyduklarını belirtmişlerdir. Sınıf öğretmenlerinin lisans öğrenimlerinde aldıkları görsel sanatlar ders içerikleri incelendiğinde programın bu ders adına gerekli bütün çıktıların sağlandığı görülmüştür. Ancak uygulama sahasında öğretmenlerin aldıkları dersler ile doğru oranda verim aldıkları düşünülmemektedir. Bunun nedeni araştırma örnekleminde bulunan, yaşı büyük ve ön lisans mezunu olan öğretmenlerimizin yeni eğitim programlarına dâhil olamamasından kaynaklandığı düşünülebilir.

Toy (2015) yaptığı araştırmada sınıf öğretmenlerinin öğretmen öz-yeterlik inançlarını araştırmış ve bulduğu sonuç bizim düşük çıkan öz-yeterlik inancımızın aksine oldukça yeterli düzeyde bulmuştur. Toy'un çalışmasını destekler nitelikte olan Benzer (2011), Doğan (2013), Eker (2014), Gençtürk (2008) çalışmalar ortaya koymuşlardır.

İkinci Alt Problem: Sınıf öğretmenlerinin cinsiyetlerine göre görsel sanatlar eğitimi alan bilgisi öz-yeterlik inançları arasında anlamlı farklılık var mıdır?

Tablo 7. Öğretmenlerin Cinsiyetlerine Göre Alan Bilgisi Öz-Yeterlik İnançları Arasındaki Farklılığa İlişkin Independent-Sample (Bağımsız Örneklem) T-Testi Sonuçlar

\begin{tabular}{cccccccc}
\hline & Cinsiyet & $\mathbf{N}$ & $\bar{X}$ & $\mathbf{S}$ & $\mathbf{t}$ & sd & $\mathbf{p}$ \\
\hline \multirow{2}{*}{ Öz-Yeterlik } & Kadın & 77 & $101,09(2,59)$ & 31,63 &, 66 & 103 &, 512 \\
& Erkek & 28 & $96,64(2,48)$ & 27,53 & & & \\
& & & & & & &
\end{tabular}

${ }^{*} p<, 05$

Tablo 7'ye göre sınıf öğretmenlerinin cinsiyetlerine göre görsel sanatlar eğitimi alan bilgisi öz-yeterlik inançları arasındaki farklılık incelenmiştir. Kadın sınıf öğretmenlerinin görsel sanatlar eğitimi alan bilgisi öz-yeterlik inançları $(X=101,09)$ ile erkek sınıf öğretmenlerinin görsel sanatlar eğitimi alan bilgisi öz-yeterlik inançları $(X=96,64)$ arasında $t(103)=, 66, p=, 512>, 05$ "e göre anlamlı farklılık olmadığı görülmektedir. Anlamlı farklılık olmamasına rağmen erkek öğretmenlerin özyeterlik inançları çok azda olsa kadın öğretmenlerin öz-yeterlik inançlarından düşük olduğu görülmektedir. Anlamlı bir farklılık olmamasına rağmen kadın öğretmenlerin yüksek düzeyde öz-yeterlik inancına sahip çıkması, kadın örneklem sayısının erkek öğretmenlere göre oldukça fazla olmasından kaynaklanmış olabilir.

Altunbaş (2011) yaptığı çalışmada kadın sınıf öğretmenlerinin daha yüksek seviyede özyeterlik düzeyine sahip olduğunu bulmuştur ve bunu, toplumun kadın öğretmenlere karşı olan bakış açısının ve kadınların öğretmenlik mesleğini kendilerine daha uygun görmelerinin neden olabileceğine bağlamıştır. Araştırmanın 2. alt problemine yönelik olarak hazırlanan anket sorularına, örneklem grubunu oluşturan sınıf öğretmenlerinin vermiş oldukları cevaplar 
incelendiğinde, ortaya çıkan bulgular Güven (2015), Kuş (2005) ve Çimen'in (2007) öz-yeterlilik ile ilgili yapmış oldukları çalışmalarında elde ettikleri “ Öğretmenlerin öz-yeterlilik inançlarının cinsiyete göre farklılaşmadığı" bulgusunu desteklemesi açısından önemlidir. Toy (2015) yaptığı araştırmada sınıf öğretmenlerinin cinsiyet değişkenine göre öğretmen öz yeterlik inançlarını incelendiğinde, öğretmen öz yeterlik inançlarında kadın öğretmenlerin öz-yeterlik inançlarının yüksek düzeyde olduğu sonucuna ulaşmıştır. Bu bulguyu destekleyen çalışmalar; Altunbaş (2011), Ekici (2006), Yavuz (2009) bulunmaktadır.

Üçüncü Alt Problem: Sınıf öğretmenlerinin yaşlarına göre görsel sanatlar eğitimi alan bilgisi özyeterlikleri inançları arasında anlamlı farklılık var mıdır?

Tablo 8. Öğretmenlerin Yaşlarına Göre Alan Bilgisi Öz-Yeterlik İnançları Arasındaki Farklılığa İlişkin One-Way Anova (Tek Yönlü Varyans) Analizi Sonuçları

\begin{tabular}{|c|c|c|c|c|c|c|c|c|c|}
\hline & Yaş & $\mathbf{N}$ & $\bar{X}$ & $S$ & $\begin{array}{l}\text { Kareler } \\
\text { Toplam }\end{array}$ & $\begin{array}{c}\text { Kareler } \\
\text { Ort. }\end{array}$ & $\begin{array}{c}\text { F } \\
(3- \\
101)\end{array}$ & p & $\begin{array}{c}\text { Post } \\
\text { Hoc } \\
\text { (Tukey) }\end{array}$ \\
\hline & $21-30$ & 17 & 94,24 & 28,33 & 14871,26 & 4957,09 & 6,11 & , $001^{*}$ & $2<3$ \\
\hline Öz- & $31-40$ & 28 & 88,04 & 33,52 & 82013,79 & 812,02 & & & \\
\hline \multirow[t]{2}{*}{ Yeterlik } & $41-50$ & 37 & 115,76 & 27,37 & 96885,05 & & & & \\
\hline & $51-60$ & 23 & 93,04 & 23,22 & & & & & \\
\hline
\end{tabular}

${ }^{*} p<, 05$ Kategoriler: $21-30=1 ; 31-40=2 ; 41-50=3 ; 51-60=4$

Tablo 8'e bakıldığında sınıf öğretmenlerin yaşlarına göre görsel sanatlar eğitimi alan bilgisi öz-yeterlik inançları arasında $\mathrm{F}(3-101)=6,11, \mathrm{p}=, 001<, 05$ 'e göre anlamlı farklılık olduğu görülmektedir. Bu anlamlı farklılık, "41-50” yaş aralığına sahip olan sınıf öğretmenlerinin özyeterlik inançlarının (=115,76), "31-40" yaş aralığına sahip olan sınıf öğretmenlerinin öz-yeterlik inançlarından $(=88,04)$ fazla olmasından kaynaklanmaktadır.

Araştırmadan elde edilen bulgular incelendiğinde sınıf öğretmenlerinin görsel sanatlar eğitimi alan bilgisine yönelik öz-yeterlilik inançlarının mesleklerinin ilk yıllarını oluşturan 21-30 yaş aralığında düşük olduğu, 30- 40 yaş aralığından kısmen daha düştüğü ancak 41- 50 yaş aralığında anlamlı fark oluşturacak şekilde yükseldiği sonucuna ulaşılmıştır. Bu bulgulara göre; sınıf öğretmenlerinin görsel sanatlar eğitimi alan bilgisine yönelik özyeterlik inançları, mesleki anlamda yeni başlamanın verdiği idealizm heyecanı, uygulama ve tecrübe yetersizliği gibi etmenlerden, 21-30 yaş aralığında düşük olduğu, 31-40 yaşları arasında mesleki heyecanda düşüşle beraber, görsel sanatlar eğitimi alan bilgisi öz-yeterlilik inancında düşüş olduğu söylenebilir. Ancak bu düşüşün yaş ile beraber ortaya çıkan tecrübe ile birlikte 41-50 yaş aralığında oldukça yükseldiği sonucu çıkarılabilir.

Burada ortaya çıkan bulgular Benzer(2011) ve Türk(2008) 'in öz yeterlilik ile ilgili yapmış olduğu çalışmalarla da paralellik göstermesi açısından önemli sayılabilir.

Dördüncü Alt Problem: Sınıf öğretmenlerinin öğrenim kademelerine göre görsel sanatlar eğitimi alan bilgisi öz-yeterlikleri inançları arasında anlamlı farklılık var mıdır? 
Tablo 9. Öğretmenlerin Öğrenim Kademelerine Göre Alan Bilgisi Öz-Yeterlik İnançları Arasındaki Farklılığa İlişkin Bağımsız Örneklem T-Testi Sonuçları

\begin{tabular}{lccccccc}
\hline & Öğrenim Kademesi & $\mathbf{N}$ & $\bar{X}$ & $\mathbf{S}$ & $\mathbf{t}$ & $\mathbf{s d}$ & $\mathbf{p}$ \\
\hline \multirow{2}{*}{ Öz-Yeterlik } & Ön Lisans & 18 & $86,50(2,22)$ & 28,43 & 2,08 & 228 &, $040^{*}$ \\
& Lisans & 87 & $102,68(2,63)$ & 30,36 & & & \\
\hline
\end{tabular}

${ }^{*} p<, 05$

Tablo 9'a bakıldığında sınıf öğretmenlerinin mezun oldukları öğrenim kademelerine göre görsel sanatlar eğitimi alan bilgisi öz-yeterlik inançları arasındaki farklılık incelenmiştir. Ön Lisans mezunu olan sınıf öğretmenlerinin öz-yeterlik inançları $(X=86,50)$ ile lisans mezunu olan sınıf öğretmenlerinin öz-yeterlik inançları $(X=102,68)$ arasında $t(228)=2,08, p=, 040<, 05$ "e göre anlamlı farklılık olduğu görülmektedir. Bu anlamlı farklılık, Lisans mezunu olan sinıf öğretmenlerinin öz-yeterlik inançlarının, ön lisans mezunu olan sınıf öğretmenlerinin öz-yeterlik inançlarından büyük olmasından kaynaklanmaktadır.

Araştırmanın örneklemini oluşturan sınıf öğretmenlerinin mezun oldukları öğrenim kademesine göre öz-yeterlilik durumlarının değişkenlik göstermesi dikkat çekici bulunmuştur. Lisans ve ön lisans mezunu sınıf öğretmenlerinin öz-yeterlilik inançları arasında oluşan anlamlı farklılığın, öğrenim süresine bağlı olarak bilgisel donanım anlamında almış oldukları eğitimden kaynaklandığı söylenebilir. Lisans ve ön lisans mezuni sınıf öğretmenleri arasında anlamlı bir farklılık olması lisans mezunu öğretmenlerin, ön lisans mezunu öğretmenlerine göre sayısı oldukça fazla olmasından kaynaklanmış olabilir.

Beşinci Alt Problem: Sınıf öğretmenlerinin mesleki kıdemlerine göre görsel sanatlar eğitimi alan bilgisi öz-yeterlik inançları arasında anlamlı farklılık var mıdır?

Tablo 10. Öğretmenlerin Mesleki Kıdemlerine Göre Alan Bilgisi Öz-Yeterlik İnançları Arasındaki Farklılığa İlişkin One-Way Anova (Tek Yönlü Varyans) Analizi Sonuçları

\begin{tabular}{|c|c|c|c|c|c|c|c|c|c|}
\hline & $\begin{array}{c}\text { Mesleki } \\
\text { Kıdem }\end{array}$ & $\mathbf{N}$ & $\bar{X}$ & $S$ & $\begin{array}{l}\text { Kareler } \\
\text { Toplam }\end{array}$ & $\begin{array}{c}\text { Kareler } \\
\text { Ort. }\end{array}$ & $\begin{array}{c}F \\
(3-101)\end{array}$ & $\mathrm{p}$ & $\begin{array}{c}\text { Post } \\
\text { Hoc } \\
\text { (Tukey) }\end{array}$ \\
\hline \multirow{5}{*}{$\begin{array}{l}\text { Öz- } \\
\text { Yeterlik }\end{array}$} & 10 yil ve & 24 & 75,92 & 31,86 & 21378,33 & 10689,16 & 14,44 &, $000^{*}$ & $1<3$ \\
\hline & altı & & & & & \multirow{4}{*}{740,26} & & & \multirow[t]{4}{*}{$2<3$} \\
\hline & $11-15$ yıl & 24 & 96,92 & 26,77 & 75506,72 & & & & \\
\hline & 16 ve & 57 & 111,26 & 25,24 & 96885,05 & & & & \\
\hline & Üstü Yil & & & & & & & & \\
\hline
\end{tabular}

${ }^{*} p<, 05$ Kategoriler: 10 yıl ve alt $\imath=1 ; 11-15$ yıl=2;16 ve Üstü=3

Tablo 10'a bakıldığında sınıf öğretmenlerinin mesleki kıdemlerine göre görsel sanatlar eğitim alan bilgisi öz-yeterlik inançları arasında $F(2-102)=14,44, p=, 000<, 05$ 'e göre anlamlı farklılık olduğu görülmektedir. Bu anlamlı farklılık, "16 ve Üstü Yıl” mesleki kıdeme sahip olan sınıf öğretmenlerinin görsel sanatlar alan bilgisi öz-yeterlik inançlarının ( =111,26), "11-15 Y1l" mesleki kıdeme sahip olan sınıf öğretmenlerinin görsel sanatlar alan bilgisi öz-yeterlik inançlarından (=96,92) ve "10 Yıl ve Altı" mesleki kıdeme sahip olan sınıf öğretmenlerinin görsel sanatlar alan bilgisi öz-yeterlik inançlarından $(=75,92)$ büyük olmasından kaynaklanmaktadır. 
Araştırmadan elde edilen bulgular mesleki kıdemin sınıf öğretmenlerinin görsel sanatlar eğitimi alan bilgisi öz-yeterlik inançlarında anlamlı bir farklılık oluşturduğunu göstermektedir. Özelikle 16 yıl ve üstü mesleki kıdeme sahip sınıf öğretmenlerinin, özyeterlik inancı konusunda mesleki açıdan daha az kıdeme sahip 10 yıl ve altı sınıf öğretmenlerinden anlamlı bir şekilde farklıdır. Buradaki anlamlı farklılığın tecrübe ile doğru orantılı olduğu söylenebilir. Nitekim Tschannen-Moran ve Woolfolk-Hoy (2002: 6) öğretmenlerin zaman içerisinde elde ettikleri tecrübelerle etkili öğretim stratejileri ve sınıf yönetimi becerileri geliştirme imkanı bulduklarını ifade etmişlerdir. Bunların yanı sıra Say(2005) ve Benzer(2011)"in yapmış oldukları çalışmalarında mesleki kıdemin artmasıyla öz-yeterlik inancının arttığı sonucuna ulaşmış olmaları, araştırma bulgularını desteklemesi açısından önemli bulunmuştur. Gençtürk (2008) "ilköğretim okulu öğretmenlerinin öz yeterlik algıları ve iş doyumlarının çeşitli değişkenler açısından incelenmesi" adlı araştırmasında kıdem değişkeninin özyeterlilik inancı üzerinde etkili olduğu sonucuna ulaşmış. Ancak bu etkinin en çok öğrenci katılımında yeterlilik en az ise öğretimsel stratejilerde yeterlilik algısı üzerinde etkili olduğunun söylenebileceğini belirtmiştir. Araştırmada elde edilen bulguların Gençtürk'ün araştırmasındaki bulgular ile örtüşmesine yola çıkarak, mesleki kıdem değişkeninin sınıf öğretmenlerinin öz-yeterlik inançları üzerinde etkili olduğu söylenebilir. Ayrıca Dönmez (2011)'in "sınıf öğretmenlerinin fen ve teknoloji dersi özyeterlik inançlarının denetim odağına göre farklılığının incelenmesi üzerine bir araştırma" konulu çalışmasında mesleki kıdemin öz-yeterlik inancı üzerinde etkili olduğu sonucuna ulaşmış olmasının, araştırma bulgularını desteklemesi açısından önemli olduğu söylenebilir. Eker (2014), sınıf öğretmenlerinin öz-yeterlik inanç düzeyleri üzerine yaptığı araştırmada öğretmenlerin öz yeterlik düzeyinin beklenen seviyeye gelmesi için öğretmenlerin birbirleri ile bilgi ve tecrübelerini paylaşmalarına, artık günümüz iletişim çağında gelişen teknoloji ile daha kolay iletişim kurup mesleki tecrübelerini iletişim araçları sayesinde bilgiyi kolay aktarabilme gibi olanaklar sayesinde eksik yanlarının daha kolay bir şekilde giderilebileceğini savunmuştur. Bunun için mesleki kıdemi yüksek olan sınıf öğretmenlerinin daha az mesleki kıdeme sahip olan sınıf öğretmenleri ile mesleki tecrübelerini paylaşmalarının bu konuda eksikliklerin giderilmesi için fayda sağlayacağı düşünülmektedir.

Altıncı Alt Problem: Sınıf öğretmenlerinin eğitim verilen sınıf düzeyine göre görsel sanatlar eğitimi alan bilgisi öz-yeterlikleri inançları arasında anlamlı farklılık var mıdır?

Tablo 11. Öğretmenlerin Eğitim Verilen Sınıf Düzeyine Göre Alan Bilgisi Öz-Yeterlik İnançları Arasındaki Farklılığa İlişkin One-Way Anova (Tek Yönlü Varyans) Analizi Sonuçları

\begin{tabular}{|c|c|c|c|c|c|c|c|c|c|}
\hline & Yaş & $\mathbf{N}$ & $\bar{X}$ & $S$ & $\begin{array}{l}\text { Kareler } \\
\text { Toplam }\end{array}$ & $\begin{array}{c}\text { Kareler } \\
\text { Ort. }\end{array}$ & $\begin{array}{c}F \\
(3- \\
101)\end{array}$ & p & $\begin{array}{c}\text { Post } \\
\text { Hoc } \\
\text { (Tukey) }\end{array}$ \\
\hline & 1. Sinif & 19 & 91,53 & 36,60 & 7368,01 & 2456,00 & 2,77 & , $045^{*}$ & $1<4$ \\
\hline Öz- & 2. Sinif & 25 & 92,60 & 28,45 & 89517,04 & 886,31 & & & $2<4$ \\
\hline \multirow[t]{2}{*}{ Yeterlik } & 3. Sinif & 25 & 97,40 & 21,42 & 96885,05 & & & & $3<4$ \\
\hline & 4. Sinif & 36 & 111,14 & 31,61 & & & & & \\
\hline
\end{tabular}

${ }^{*} p<, 05$ Kategoriler: 1. Sinff $=1 ; 2$. Sinf $=2 ; 3$. Sinnf $=3 ; 4$. Sinı $=4$

Tablo 11'e bakıldığında sınıf öğretmenlerinin eğitim verdikleri sınıf düzeylerine göre özyeterlik inançları arasında $F(3-101)=2,77, p=, 045<, 05$ "e göre anlamlı farklılık olduğu görülmektedir. Bu anlamlı farklılık, 4. sınıf düzeyinde eğitim veren sınıf öğretmenlerinin alan 
bilgisi öz-yeterlik inançlarının $(X=111,14), 1$. sınıf düzeyinde eğitim veren sınıf öğretmenlerinin alan bilgisi öz-yeterlik inançlarından $(X=91,53), 2$. sınıf düzeyinde eğitim veren sınıf öğretmenlerinin alan bilgisi öz-yeterlik inançlarından $(X=92,60)$ ve 3 .sınıf düzeyinde eğitim veren sınıf öğretmenlerinin alan bilgisi öz-yeterlik inançlarından $(X=97,40)$,büyük olmasından kaynaklanmaktadır. Araştırmadan elde edilen bulgular 4. sınıf düzeyinde eğitim veren sınıf öğretmenlerinin 1. 2. ve 3. sinıf düzeyinde eğitim veren sinıf öğretmenlerine göre görsel sanatlar eğitimi özyeterlik inançlarının daha yüksek olduğunu göstermektedir. Burada ortaya çıkan anlamlı farklılığın görsel sanatlar dersi 4. sınıflar müfredat programındaki konulara hakimiyet veya çizgisel geliĢim itibari ile görsel gerçeklik evresine ulaşan öğrencilerin sanatsal eğitimine yönelik öğretmen bilgi birikimlerinin yeterli görülmesinden kaynaklandığı söylenebilir. Taranan literatürde öğretmen öz-yeterliğini eğitim verdikleri sınıf düzeyine göre farklılaştığını ortaya koyan ve bizim çalışmamız ile benzerlik gösteren çalışmalar; Varol (2007), Denizoğlu (2008), Taşkın ve Hacıömeroğlu (2010)" dır. Öğretmen öz-yeterlik inancında eğitim verilen sınıf düzeyi literatür de incelendiğinde genellikle sınıf düzeyi arttıkça öz-yeterlik düzeyinde de artış görülmektedir. Aynı zamanda durumun eğitim verilen sınıf düzeyine göre farklılaşmadığını ortaya koyan araştırmalar da Mirzeoğlu (2007) ve Akdağ ve Walter (2005) tarafında yapılmıştır.

\section{TARTIŞMA}

Araştırmanın bulguları birlikte ele alınıp değerlendirildiğinde sınıf öğretmenlerini özyeterlilik inançlarının bazı değişkenlere göre düşük olduğu tespit edilmiştir. Bu çalışmanın alanda ciddi bir sorunu ele aldığı düşünülmektedir. İlkokullarda Görsel Sanatlar dersi sınıf öğretmenleri tarafından yürütülmekte veya farklı derslerin uygulama alanı olarak görülmektedir. Bu açıdan bakıldığında araştırma görsel sanatlar eğitiminin ilkokul müfredat programı uygulayıcıları olan sınıf öğretmenlerinin alana yönelik eksikliklerinin farkına varılması ve bu eksikliklerin giderilmesi için çözüm önerileri sunulması açısından önemlidir. Sınıf öğretmenlerine uyguladığımız bu anket sırasında öğretmenlerin ortak düşüncesi; Görsel Sanatlar dersi hakkında genel bir bilgiye sahip oldukları ancak alana bilgisine, öğrencilerin gelişim düzeylerine, yaratıcı düşüncel uygulamalarına, sanatın farklı alanlarına ve öğrencinin estetik algısını geliştirici düzeyine dair uygulamalar yapamadıklarının farkındalar. Görsel sanatlar dersine yönelik alan bilgisine sahip olan sınıf öğretmenlerinin öz-yeterlilikleri ile doğru oranda artmaktadır. Öz-yeterliliği yüksek çıkan sınıf öğretmenlerinin değişkenlerinde dikkat çeken özellikler yaş ile tecrübe kazanmaları, lisans mezunu öğretmenlerimizin eğitim yılı olarak ön lisansa göre daha fazla eğitim süresine sahip olmaları, mesleki kıdemlerinde yıl ile deneyimlerinin artması ve ilköğretimin son sınıf kademesinde ders vererek öğrencilerini ve kendisini daha iyi tanıyor olmaları öz- yeterliliklerini yükseltmiştir. Öz-yeterliliği düşük çıkan öğretmenlerimizin yaş ya da mesleki kıdemlerine bakılmaksızın bilgi ve deneyimlerini arttırılması yönünde çalışmalara ağırlık verilmesi gerekmektedir.

İlkokul görsel sanatlar dersinde yeterli alan bilgisine sahip olmayan sınıf öğretmenlerinin, olası yanlış öğretim yöntem ve teknikleri kullanımı neticesinde ortaya çıabilecek ve bireyin sanatsal gelişimine olumsuz etki edebilecek etmenlerin ortadan kaldırılması, Ayn zamanda öğrenciyi eleştirel düşünmeye sevk etmek, gözlem ve sentez yeteneğini artırmak ve de en önemlisi görsel sanatlar dersinin bir ifade dersi olduğu ilkesinden hareketle, sadece yetenekli öğrencilerin alması gereken salt bir yetenek dersi olarak gören anlayıştan kurtarmak için Görsel Sanatlar dersine branş öğretmenlerinin girmesi üzerinde düşünülmesi gereken bir konudur.

$\mathrm{Bu}$ çalışmadan yola çıkılarak, çalışma evreni daha da genişletilip üzerine çalışma ve araştırma yapılması sağlanabilir. Öğretmenlerin de bu konu hakkında kendilerinin öz- 
yeterliliklerinin düşük olmasının farkında olmaları mevcut olan bir sorunu açıklığa kavuşturulması için çalışmaların devam etmesi gerekmektedir.

\section{SONUÇ}

Sınıf öğretmenlerinin görsel sanatlar dersinde alana ilişkin öz-yeterlilik inançlarını ortaya çıkarmayı amaçlayan bu araştırmada ulaşılan sonuçlar aşağıdaki gibidir:

Öğretmenlerin öz-yeterlikleri 39 maddelik algı ölçeğine vermiş oldukları cevaplardan yola çıkarak toplam öz-yeterlik inançlarına yönelik dağılıma, sınıf öğretmenlerinin görsel sanatlar eğitimi alan bilgisi öz-yeterlik ortalama puanları incelendiğinde düşük düzeyde inanca sahip oldukları görülmektedir.

Sınıf öğretmenlerinin cinsiyetlerine göre görsel sanatlar dersinde alan bilgisi öz-yeterlik inançları arasındaki farklılık incelenmiştir. Kadın sınıf öğretmenlerinin görsel sanatlar eğitimi alan bilgisi öz-yeterlik inançları ile erkek sınıf öğretmenlerinin görsel sanatlar eğitimi alan bilgisi öz-yeterlik inançları arasında anlamlı farklılık olmadığı görülmektedir. Anlamlı farklılık olmamasına rağmen erkek öğretmenlerin öz-yeterlik inançları çok azda olsa kadın öğretmenlerin öz-yeterlik inançlarından düşük olduğu görülmektedir.

Sınıf öğretmenlerin yaşlarına göre görsel sanatlar eğitimi alan bilgisi öz-yeterlik inançları arasında anlamlı farklılık olduğu görülmektedir. Bu anlamlı farklılık, "41-50" yaş aralığına sahip olan sınıf öğretmenlerinin öz-yeterlik inançları "31-40" yaş aralığına sahip olan sınıf öğretmenlerinin öz-yeterlik inançlarından fazla olmasından kaynaklanmaktadır.

Sınıf öğretmenlerinin öğrenim kademelerine göre görsel sanatlar eğitimi alan bilgisi özyeterlik inançları arasındaki farklılık incelenmiştir. Ön Lisans mezunu olan sınıf öğretmenlerinin alan bilgisi öz yeterlik inançları ile lisans mezunu olan sınıf öğretmenlerinin alan bilgisi öz yeterlik inançları anlamlı farklılık olduğu görülmektedir. Bu anlamlı farklılık, Lisans mezunu olan sınıf öğretmenlerinin öz-yeterlik inançlarının, ön lisans mezunu olan sınıf öğretmenlerinin öz-yeterlik inançlarından büyük olmasından kaynaklanmaktadır.

Sınıf öğretmenlerinin mesleki kıdemlerine göre görsel sanatlar eğitimi alan bilgisi özyeterlik inançları arasında anlamlı farklılık olduğu görülmektedir. Bu anlamlı farklılık, "16 ve Üstü Y1l" mesleki kıdeme sahip olan sınıf öğretmenlerinin öz-yeterlik inançlarının, "11-15 Y11" mesleki kıdeme sahip olan sınıf öğretmenlerinin öz-yeterlik inançlarından ve "10 Yıl ve Altı" mesleki kıdeme sahip olan sınıf öğretmenlerinin öz-yeterlik inançlarından büyük olmasından kaynaklanmaktadır.

Sınıf öğretmenlerinin eğitim verdikleri sınıf düzeylerine göre görsel sanatlar dersi alan bilgisi öz-yeterlik inançları arasında anlamlı farklılık olduğu görülmektedir. Bu anlamlı farklılık, 4. Sınıf düzeyinde eğitim veren sınıf öğretmenlerinin öz-yeterlik inançlarının, 1 . Sınıf düzeyinde eğitim veren sınıf öğretmenlerinin öz-yeterlik inançlarından, 2 . Sınıf düzeyinde eğitim veren sınıf öğretmenlerinin öz-yeterlik inançlarından ve 3 . Sınıf düzeyinde eğitim veren sınıf öğretmenlerinin öz-yeterlik inançlarından büyük olmasından kaynaklanmaktadır.

\section{ÖNERILER}

Sınıf öğretmenlerinin görsel sanatlar dersinde alana ilişkin öz-yeterlik inançlarını ortaya çıkarmayı amaçlayan bu araştırmada sınıf öğretmenlerinin görüşlerinin değerlendirildiği araştırma sonucuna dayanarak, programın uygulanmasında sıkıntı yaşanılan yerlerin ortaya konması, programın olumsuz yönlerinin giderilmesi için çeşitli öneriler geliştirilmiştir.

Elde edilen sonuçlar doğrultusunda geliştirilen öneriler şunlardır: 
1. Sınıf öğretmenlerinin lisans öğrenimlerinde aldıkları görsel sanatlar ders içerikleri incelendiğinde programın bu ders adına gerekli bütün çıktıların sağlandığı görülmüştür. Ancak uygulama sahasında öğretmenlerin aldıkları dersler ile doğru oranda verim aldıkları görülmemiştir. Çalıştıkları mevcut kurumlarında yürütmekte oldukları derslerde öğrencilerin öğrenim düzeylerine ve çizgisel gelişim basamaklarına uygun olmadığından bir takım aksamaların oluşmasına sebebiyet vermektedir. Sınıf öğretmenlerinin yerine görsel sanatlar dersine branş öğretmenlerinin girmesi önerilmektedir. Eğer branş öğretmenleri sağlanamıyorsa her okul için görevlendirilecek görsel sanatlar öğretmeni, derse giren sınıf öğretmenlerilenin danışmanlığını yapabilir ve yol gösterici olabilir. Bu sayede derslerin daha verimli geçmesi sağlanabilir.

2. Çocukların sanatsal ve görsel açıdan büyük eksiklikler ile bir üst kademeye geçtiklerinde derslerine giren branş öğretmenlerinin işini de oldukça zorlaşmaktadır. Bunun uzantısında sanattan uzaklaşan ve kendini sanattan soyutlayan bireyler ortaya çıkmaktadır. Uygulama okullarında yapılan anket sırasında bir çok öğretmenin de dile getirmesi, sorunun ne denli önemli olduğunu bir kez daha ortaya koymaktadır. Bu konuda daha detaylı nitel bir çalışma yapılması önerilirebilir.

3. Öğrenim kademelerine göre ön lisans mezunu olan ve mesleki kıdemi az olan sınıf öğretmenlerine öz-yeterliliklerinin, derse olan ilgisinin ve donanımının arttıılması konusunda daha öncelikli çalışmalar düzenlenmesi önerilebilir.

\section{KAYNAKÇA}

Akdağ, I., Walter, J. (2005). Öğretmen adaylarının mesleki yeterlilik duygusu. Spormetre Beden Eğitimi ve Spor Bilimleri Dergisi, 3(4), 127-131.

Altunbaş, S. (2011) İlköğretim okullarında görev yapan sını öğretmenlerinin öz yeterliklerinin incelenmesi. Yüksek Lisans Tezi, Frrat Üniversitesi Ĕ̆itim Bilimleri Enstitüsü, Elazığ.

Artut, K. (2009). Sanat eğitimi: Kuramları ve yöntemleri. Anı Yayıncılık.

Ateş, A. (2014). Güzel sanatlar eğitimi öğrencilerinin öğretmen öz yeterlilik inançlarmın incelenmesi. Yüksek Lisans Tezi. Gazi Üniversitesi Eğitim Bilimleri Enstitüsü, ANKARA

Benzer, F. (2011). İlköğretim ve ortaöğretim kurumlarında görev yapan öğretmenlerin öz yeterlik algılarının analizi. Yüksek Lisans Tezi, Selçuk Üniversitesi Eğitim Bilimleri Enstitüsü, Konya.

Büyüköztürk, Ş., Çakmak, E. K., Akgün, Ö. E., Karadeniz, Ş., \& Demirel, F. (2017). Bilimsel araştırma yöntemleri. Ankara: Pegem Akademi.

Büyüköztürk, Ş., Çokluk, Ö., Köklü, N. (2017). Sosyal bilimler için istatistik. Ankara: Pegem Akademi.

Celep, C. (2004). Meslek olarak öğretmenlik. Editör C. Celep, Meslek olarak öğretmenlik (pp. 23-49). Ankara: Anı Yayıncilık.

Çakar, F. (2013). Eğitim psikolojisi. Gündüz, B. Çarpi, B. (Ed.). Eğitim psikolojisi içinde (s.256 ). Adana: Karahan.

Çatıkkaş, D. (2014). Öğretmen adaylarının sanat eğitimi öz-yeterliklerinin araştırılması. Yüksek Lisans Tezi, Gaziosmanpaşa Üniversitesi Eğitim Bilimleri Enstitüsü, Tokat.

Çeliköz N. (2003). Öğretmenlik mesleği ve etiği. Özdemir, Ç., Ed., Öğretmenlik mesleğine giriş, ss.329-390, Asil Yayın Dağıtım, Ankara.

Çevik B. (2011) Sını öğretmeni adaylarının Müzik öğretimi öz-yeterlilik düzeylerinin incelenmesi. Ahi Evran Üniversitesi Eğitim Fakültesi Dergisi, 12(1), 145-168

Çimen, S. (2007). İlköğretim öğretmenlerinin tükenmişlik yaşantıları ve yeterlik algıları. Yüksek Lisans Tezi, Kocaeli Üniversitesi Sosyal Bilimler Enstitüsü, Kocaeli. 
Çokluk, Ö., Şekercioğlu, G., \& Büyüköztürk, Ş. (2010). Çok değişkenli istatistik SPSS ve LISREL uygulamaları (Birinci baskı). Pegem Akademi Yayınları, Ankara.

Demirbaş, M., \& Yağbasan, R. (2005). Sosyal öğrenme teorisine dayalı öğretim etkinliklerinin, öğrencilerin bilimsel tutumlarının kahıcılı̆̆ına olan etkisinin incelenmesi. Uludağ Üniversitesi Eğitim Fakültesi Dergisi, 18(2), 161-180.

Denizoğlu, P. (2008). Fen bilgisi öğretmen adaylarının fen bilgisi öğretimi öz-yeterlik inanç düzeyleri, öğrenme stilleri ve fen bilgisi ögrretimine yönelik tutumları arasındaki ilişkinin değerlendirilmesi. Yüksek Lisans Tezi, Çukurova Üniversitesi, Adana.

Dilmaç, O., \& İnanç, C. (2015). Sınıf öğretmenlerinin görsel sanatlar dersine yönelik öz yeterlik düzeyleri. Bartın Üniversitesi Eğitim Fakültesi Dergisi, 4(2), 382-400.

Doğan, S. (2013). Sinı öğretmenlerinin öz yeterlik algısı ve öğretmenlik mesleğine yönelik tutumlarının incelenmesi: A ̆ğr ili örneği. Yüksek Lisans Tezi, Erzincan Üniversitesi Sosyal Bilimler Enstitüsü, Erzincan.

Dönmez, S. (2011). Sinıföğretmenlerinin fen ve teknoloji dersi öz-yeterlilik inançlarının denetim odağına görefarklılı̆̆ıın incelenmesi üzerine bir araştırma. Yüksek Lisans Tezi, Afyon Kocatepe Üniversitesi Sosyal Bilimler Enstitüsü, Afyonkarahisar.

Eker, C. (2014). Sınıf öğretmenlerinin öz-yeterlilik inanç düzeyleri üzerine bir araştırma. Uşak Üniversitesi Sosyal Bilimler Dergisi, 7(1), 162-178.

Ekici, G. (2006). Meslek lisesi öğretmenlerinin öğretmen öz-yeterlik inançlari üzerine bir araştırma. Eurasian Journal of Educational Research (EJER), 24, 87-96.

Erden, M. (1998). Öğretmenlik mesleğine giriş, İstanbul: Alkım.

Ertemin, B. (1997). İlköğretim okulları resim-işöğretim programının değerlendirilmesi. Yüksek Lisans Tezi, Anadolu Üniversitesi Eğitim Bilimleri Enstitüsü, Eskişehir.

Fraenkel, J. R., Wallen, N. E., \& Hyun, H. H. (2011). How to design and evaluate research in education. New York: McGraw-Hill Humanities/Social Sciences/Languages.

Gençaydın, Z. (1990). Sanat eğitiminin düşünsel temelleri: Orta öğretim kurumlarında resim-işöğretimi ve sorunları. Ankara: TED Yayınları.

Gençtürk, A. (2008). İlköğretim okulu öğretmenlerinin öz-yeterlik algıları ve iş doyumlarımın çeşitli değiş̧kenler açısından incelenmesi. Yüksek Lisans Tezi, Zonguldak Karaelmas Üniversitesi, Zonguldak.

Gültekin, M. (2000). İlköğretim birinci basamakta kimi derslerin öğretiminde dal öğretmenlerinden yararlanma. Anadolu Üniversitesi Eğitim Fakültesi Dergisi, 10(2), 105-125.

Güven, S. (2005). Devlet okullarn ilköğretim birinci kademede çalışan İngilizce öğretmenlerinin profili ve yeterlik algıları. Yüksek Lisans Tezi, Mersin Üniversitesi Sosyal Bilimler Enstitüsü, Mersin.

Henson, R. K. (2001). Teacher self-efficacy: substantive implications and measurement dilemmas teacher self-efficacy: substantive implications and measurement dilemmas. Teacher Efficacy Research, January 26.

Hoy, A. W., \& Spero, R. B. (2005). Changes in teacher efficacy during the early years of teaching: A comparison of four measures. Teaching and Teacher Education, 21(4), 343-356.

Kalkan, M. (2012). Sosyal öğrenme kuramı. Özbay Y.\& Erkan S. (Ed.). Eğitim psikolojisi (s.249). Ankara: Pegem.

Kırışoğlu, O. T. (2002). Sanatta eğitim, görmek öğrenmek yaratmak (2. Bask1). Ankara: Pegem Yayıncilik. 
Kuş, B. B. (2005). Öğretmenlerin bilgisayar öz-yeterlik inançlar ve bilgisayar destekli öğretime yönelik tutumları. Hacettepe Üniversitesi Fen Bilimleri Enstitüsü Ankara.

Leech, N., Barrett, K., \& Morgan, G. A. (2013). SPSS for intermediate statistics: Use and interpretation. Routledge.

Mirzeoğlu, D., Akdă̆, I., \& Boşnak, M. (2007). Beden eğitimi öğretmenlerinin, öğretmen adaylarının, beden eğitimi ve spor yüksekokullarında görev yapan öğretim elemanlarının mesleki yeterlik duygusunun karşılaştırılması. Hacettepe Üniversitesi Spor Bilimleri Dergisi, 18, 109-125.

Milli Eğitim Bakanlığı Ortaöğretim Genel Müdürlüğü. (2006). Tanıtım ve yönlendirme dersi. Ankara: Milli Eğitim Bakanlığı Yayınları.

Özdamar, K. (2001). Paket programlar ve istatistiksel veri analizi (çok değişkenli analizler) (4. Baskı). Eskişehir: Kaan Yayınları.

Özen, Y., \& Gül, A. (2007). Sosyal ve eğitim bilimleri araştirmalarinda evren-örneklem sorunu. Atatürk Üniversitesi Kazım Karabekir Ĕ̆itim Fakültesi Dergisi, 15, 394-422.

Özerkan, E. (2007). Öğretmenlerin öz-yeterlik algıları ile öğrencilerin sosyal bilgiler benlik kavramları arasındaki ilişki, Yüksek Lisans Tezi, Trakya Üniversitesi Sosyal Bilimler Enstitüsü, Edirne.

San, I. (1977). Sanatsal yaratma ve çocukta yaraticilik. Ankara: Türkiye Is Bankasi Yayınları.

San, İ. (1983). Sanat eğitimi kuramları. Tan Yayınları:25, Eğitim Dizisi:1. Ankara: Özen Matbaacılık.

Say, M. (2005). Fen bilgisi öğretmenlerinin öz-yeterlilik inanışları. Yüksek Lisans Tezi, Marmara Üniversitesi Eğitim Bilimleri Enstitüsü, İstanbul.

Taşkın, Ç. İ., \& Hacıömeroğlu, G. (2010). Öğretmen öz-yeterlik inanç ölçeğinin Türkçeye uyarlanması ve sınıf öğretmeni adayların öz-yeterlik inançları. Dokuz Eylül Üniversitesi Buca Eğitim Fakültesi Dergisi, 27, 63-75.

Terzi, A. Barut, Y., \& Gürsoy, A. (2003) Öğretmenlik mesleğine giriş. Ankara. Bursa Teknik.

Tezbaşaran, A. A. (1997). Likert tipi ölçek geliştirme klavuzu. Türk Psikologlar Derneği.

Toy, S. N. (2015). Sınıföğretmenlerinin öğretmen öz yeterlikleri ile kaynaştırma eğitimine ilişkin yeterlik inançlarının karşılaştırılması. Yüksek Lisans Tezi, Pamukkale Üniversitesi Eğitim Bilimleri Enstitüsü, Denizli.

Tschannen-Moran, M., \& Woolfolk Hoy, A. (2002, April). The influence of resources and support on teachers' efficacy beliefs. In annual meeting of the American Educational Research Association, New Orleans, LA

Türk, Ö. (2008). İlköğretim sını öğretmenlerinin öz yeterlikleri ve mesleki doyumlarının incelenmesi. Yüksek Lisans Tezi, Yeditepe Üniversitesi Sosyal Bilimler Enstitüsü, İstanbul.

Türkdoğan, G. (1984). Sanat eğitimi yöntemleri. Ankara: Kadığlu Matbaası.

Türkkan, B. (2011). Görsel sanatlar öğretimi dersindeki uygulamaların meslek yaşamında kullanabilirliğine ilişkin sınıföğretmeni adaylarının görüşleri. E-journal of New World Sciences Academy. 6(1).

Varol, B. (2007). Beden eğitimi ve spor öğretmenliği bölümü öğrencilerinin öğretmenlik mesleğine ilişkin öz-yeterlikleri. Yüksek Lisans Tezi, Niğde Üniversitesi Sosyal Bilimler Enstitüsü, Nigde.

Yavuz, D. (2009). Öğretmen adaylarının öz-yeterlik algılar ve üstbilişsel farkındalıklarının çeşitli değişkenler açısından incelenmesi. Yüksek Lisans Tezi, Zonguldak Karaelmas Üniversitesi Sosyal Bilimler Enstitüsü, Zonguldak. 
Yükselgün, Ö., \& Türkcan, B. (2012). İlköğretim görsel sanatlar dersi öğretim programindaki "görsel sanat kültürü" öğrenme alanının uygulanması. Yüksek Lisans Tezi, Abant İzzet Baysal Üniversitesi Sosyal Bilimler Enstitüsü Dergisi, Eskişehir. 